European journal of American studies

Special Issue: Envisioning Justice: Mediating the Question of Rights in American Visual Culture

\title{
Just(ice) Smiling? Masks and Masking in the Occupy-Wall Street Protests
}

Andreas Beer

\section{(2) OpenEdition}

\section{Journals}

Electronic version

URL: https://journals.openedition.org/ejas/13982

DOI: $10.4000 /$ ejas. 13982

ISSN: 1991-9336

Publisher

European Association for American Studies

Electronic reference

Andreas Beer, "Just(ice) Smiling? Masks and Masking in the Occupy-Wall Street Protests", European journal of American studies [Online], 13-4 | 2018, Online since 07 March 2019, connection on 08 July 2021. URL: http://journals.openedition.org/ejas/13982 ; DOI: https://doi.org/10.4000/ejas.13982

This text was automatically generated on 8 July 2021.

Creative Commons License 


\title{
Just(ice) Smiling? Masks and Masking in the Occupy-Wall Street Protests
}

\author{
Andreas Beer
}

\section{Introduction}

1 When the Occupy Wall Street-protests (OWS) erupted in New York City in 2011, they constituted-on the one hand-the localized adaption of a global surge of uprisings that had begun with the so-called Arab Spring, had been picked up by people in Jemen, Bahrain, Israel and elsewhere in the Middle East and Northern Africa, and had also taken hold in the Spanish indignad@s-movement. These movements had diverse grievances, tactics and goals, but at least the European and the North American variant prominently put questions about justice in a late modern society (and democracy) on their banners. Protesters discussed and demanded new social relations and answers to problems of representation and participation that had become manifest in the recent economic crisis but went further than fiscal policy. ${ }^{1}$

2 The following article discusses the OWS-protests' points of imbrication with notions of social justice. It argues that underlying conceptions of social justice relied upon the alter-globalization protests of the late 1990s and early 2000s and adopted practices of organization and performances from these precursors. OWS, albeit often referred to as a politically "neutral" movement-being "neither left nor right"-thus referred to a decidedly left critique of globalization. After outlining historical references between the two protest cycles, the article details the prominent usage of masks in these performances and then zooms in on one particularly salient mask for OWS-that of the British folktale character Guy Fawkes. Via a close reading of the superhero comic $V$ for Vendetta and its film adaptation, this mask is contextualized within several medial environments that provided a narrative blueprint for OWS. Finally, the article outlines the strands of a broader discussion about the limitations of superhero narratives (with 
their often strict duality between good and evil) for the ideas of social justice discussed within OWS. The recognition of these limitations, the article argues, underlines the very ambiguities inherent in the open organizational structure of the Occupy-protests; a structure that effectively prevented new visions of justice to emerge.

\section{2. "The blatant injustices of our times": Occupy Wall Street, Social Justice and the Afterlife of the Alter- globalization Movement}

"On September 17, 2011, people from all across the United States of America and the world came to protest the blatant injustices of our times perpetuated by the economic and political elites. On the 17th we as individuals rose up against political disenfranchisement and social and economic injustice." These are the opening sentences of the "Principles of Solidarity," one of the major statements that emerged from the Occupy Wall Street-protests in New York City. ${ }^{2}$ While the initial call for the protests had refrained from formulating any demands and rather put the provocative question "What is our one demand?" front and center, in the days and weeks that followed, protesters at the various Occupy-sites around the globe did indeed enunciate a plethora of demands. ${ }^{3}$ As the one just quoted, most of them emanated from the impression that the workings of "the system" were deeply "unjust", i.e. detrimental to the common sense of justice of the gathered populace. The "Declaration of the Occupation of New York City," another pamphlet digitally issued by the protesters, acknowledged in its very first sentence that they had gathered "to express a feeling of mass injustice" ("Declaration").

While the initial grievances articulated in the first few days at Zuccotti Park revolved around the incentives the Obama administration had offered to troubled banks while neglecting debt-ridden middle-class families and specifically homeowners threatened by foreclosures, the protesters quickly established the moral dimension as a fundamental level of the discussion, steering the debate away from questions of appropriate or inappropriate fiscal measures towards an ethical evaluation of the political system as such. Concepts of justice and the rights of individuals vis-à-vis the political system were thus discussed in an emphatic sense; not simply as compliant with existing laws or judicial administration, but as specific actions and procedures that were morally "right" and "fair." This ethical dimension of the perceived injustice(s) allowed for a more personal attachment to the otherwise highly technical policy decisions taken on the national as well as state level (Roth n.p.). The notion that "banks got bailed out, people got sold out" in the post-2008 financial crisis reverberated strongly with the Occupiers and their sympathizers because many of them had experienced an economic squeeze first hand themselves, either concerning housing mortgages or student loans (Gitlin; Kraushaar). ${ }^{4}$

5 In the "Principles of Solidarity" the protesters "dar[ed] to imagine a new socio-political and economic alternative that offers greater possibility of equality," thereby inscribing their quest for economic well-being into concepts of social justice which specifically insist on the reciprocal relationship between the individual and society and are informed by the notion of economic inclusion. From the perspective of these concepts, distributive means like taxation, the creation or maintenance of a social security net, 
and opportunities for socio-economic mobility are regarded as indispensable preconditions for a just society, which does not aim at economic equity, but acknowledges the economic sphere as fundamental to other social realities. Without negating conceptions of justice that concentrate on power relations in the realm of communication and identification, the social justice approach regards economic factors as central for the disparities of exclusion-both on national and transnational levels. Following John Rawls' A Theory of Justice and Rawls' dictum that justice is fairness, any kind of exclusion is perceived as unjust since it precludes a fully democratic participation of and debate among individuals. This nexus between social justice and democratic participation has been put front and center by the alter-globalization movement, which was a loose federation of several national protest movements formed in the late 1990s and early 2000s as an antagonistic collective player against economic interests that were perceived as advancing a market-liberal agenda ("corporate globalization"). The alter-globalization movement was regarded as the organizational antagonist to transnational economic actors such as the World Bank, the World Trade Organization, and the International Monetary Fund. ${ }^{5}$

6 The alter-globalization movement-also known as the global justice movementjuxtaposed the unifying logics of the economic actors with the plural logics of rhizomatic, contingent cooperation between a variety of regional actors, thus earning it the sobriquet "movement of movements." The media often reported on the alterglobalization movement as a transnational structure, with its impressive protests (e.g., in Seattle 1999, in Genoa 2001, or during the heydays of the World Social Forum in Porto Alegre, 2001 till roughly 2004) relying on the knack of the organizers to connect local and regional actors with inter- and transnational institutions. The movement included churches, political parties, non-governmental organizations and the Jubilee 2000-campaign as well as organizational helpers like attac or Peoples' Global Action. ${ }^{6}$ On the one hand, this plurivocal, border-crossing approach helped to boil down transnational grievances into tangible local forms of resistance and on the other hand made it possible to translate local practices into a wider, notionally global, context. The alter-globalization movement (or network) eschewed hierarchical organization and preferred a rhizomatic approach in the sense that every instance (or node) of the network could act for itself and connect its struggles with other instances of the network, without prior discussion or even consent of a higher authority. This rhizomatic connectability applied to the representations of resistance as well: Devices, forms, and actions that had a local history of (limited) success were tested and incorporated into a transnational and intercultural symbolic repertoire. One example is the confrontational performative practice of the Tute Bianche ("white overalls"): Protesters wore white, abundantly padded overalls, which allowed them to withstand the blows of batons and-when marching en bloc-effectively break through police lines without using force apart from the momentum of their unified movement. This militant practice originated in the mid-1990s in the Italian left, and after members successfully used this tactic in a protest in Prague in 2000, it was adopted (and often changed according to local criminal laws) by various regional groups.

7 The history of social justice and the alter-globalization movement is paramount for OWS as its key organizers were politicized in this environment, especially in the transnational support network of the Mexican guerrilla group Ejército Zapatista de Liberación Nacional (EZLN or Zapatistas). ${ }^{7}$ The Zapatistas popularized horizontal decision-making and processes of deliberation intended to reach a consensus in all 
decisions discussed by the community, thus attempting to maximize individual involvement in democratic practices. ${ }^{8}$ In an act of hemispheric borrowing, the first OWS activists wove practices from the so-called Global South into the fabric of Occupy Wall Street's organizational structure. Thanks to their pivotal positions as facilitators and discussion leaders, these experienced organizers implemented horizontal decisionmaking processes in the so-called General Assemblies, in which all participants had voting as well as blocking powers. As all decisions had to be made unanimously (seeking consensus, not majorities), every participant had to signal at least silent affirmation for any given topic. The initial absence of specialized working groups or committees and the denial to name spokespersons or other representatives supported OWS's efforts to stall incorporation into institutional frames of politics, mirroring the Zapatistas' reliance on alternative political spaces and logics. OWS's organizational structure as well as their approach to social justice can thus be seen as an adaption of ideas proposed by the alter-globalization movement a decade earlier. While the alterglobalization movement-including many indigenous people-decried the structural exploitation of the "Global South" by the economically advanced countries of "the North" and called for "global justice," the college-educated, mostly white, middle-class members of OWS focused on the social inequalities in the US, arguing that the justice they sought had to be brought along by distributive changes in the economic sphere at home. ${ }^{9}$

\section{From Subcomandante to Everybody's Guy: Different Logics of Masking}

8 A characteristic feature of many alter-globalization protests was the festive, carnivalesque atmosphere the protesters created with their performances to counteract the threat of uniformity that in their view emanated from "corporate globalization." The perception that the world is governed by men in uniform business suits, following a uniform logic of infringements of social rights and privatizations of common goods, motivated the different actors to create spectacles that opposed this uniformity on a visual level. Catering to the media attention and logics, performances included so-called Reclaim the Streets carnivals, which often included subversive acts like damaging surveillance devices or cracking the street's concrete to plant flowers. Other performances saw the Clandestine Insurgent Rebel Clown Army, dressed up in colorful and individual clown costumes, engaging police forces with flower bombardments, water pistols and hugging attacks to expose, ridicule, and counteract police brutality. Such tactics constituted a break with the militancy that the aforementioned Tute Bianche still favored. The use of almost comical extremes of pacifism and "tactical frivolity" was an attempt to communicate the protesters' demands to international media outlets that rely on the translation of systemic conflicts into (often binary) images, associating corporate actors and state organs like the police with violence and ill-humor and the protesters with freedom, creativity and fun (see Sobral 239-245).

9 The visual and performative culture of OWS was clearly steeped in such ideas and logics of representation. Many observers have underlined the creativity, self-reflexivity, and irony prevalent in the Occupy protests, while some criticized that at its core, Occupy was nothing more than a spectacle of aesthetics that focused on "affective intensities" 
(Taussig 40). The creative output at the encampments, though, marks a paradigmatic shift: While the alter-globalization movement performed most of its large-scale protests as events antagonistic to the force of "corporate globalization," the performances of OWS were not directed against any discernible actors. Although banks or government actors were named as culprits for the current crisis, the protests did not engage them or their agendas but rather transcended them. Prioritizing systemic questions meant that a multitude of voices emerged with a plethora of demands and possible solutions but not one unified enemy. "We are the 99 per cent," the most famous slogan of the 2011 protests, means that almost anybody was invited to join the congregations, marches, and online campaigns; the messages and performances asked for affective association and not strategic cooperation along shared political enemies.

This difference becomes obvious when comparing two masks that featured heavily in the two protests: the black ski-mask popularized by the Mexican Zapatistas in the alterglobalization movement and what is alternatively known as Occupy-, Guy Fawkes-, or Anonymous-mask in the OWS-protests. ${ }^{10}$ The ski-mask, worn by the Mexican indigenous guerrillas and, most famously, by its spokesperson Subcomandante Marcos, is supposed to work on two symbolic fronts: first, to erase the facial features of its indigenous wearers so that they do not have to face racist exclusions, injustices, and criminal persecution. When worn by non-indigenous sympathizers, the mask allows them to incorporate their own individual struggles into the armed rebellion of the Zapatistas, as the latter foster an open form of indigeneity based on social affiliation rather than ethnic belonging. ${ }^{11}$ The well-known phrase coined by Subcomandante Marcos, "Behind us [our masks] we are you," verbalizes a strategy that attempts to join the struggle of the indigenous Mexicans (supposedly continuing a 500-year struggle against colonizers and colonial practices) with struggles against perceived neo-imperial behavior by the actors connected with "corporate globalization." ${ }^{12}$ This means that the ski-mask serves as an entry point into the rebellion which is based on supposedly indigenous concepts of conviviality and uprising. The focal point of this act of identity shift is thus the persona (not necessarily the person) of Subcomandante Marcos; temporarily the mask turns the wearer into an antagonist of neo-liberalism. It thus offers just one position for protesters, a position determined by the Zapatistas.

The Occupy-mask-the representation of a white male face with black eyebrows and a black goatee, high cheekbones, and an ambiguous smile-is based on the supposed facial features of Guy Fawkes, a historical figure central to the so-called Gunpowder Plot of 1605. The incident refers to a group of Catholics who were arrested on charges of having planned to blow up King James I, a protestant, and the Houses of Parliament in London. One of the men arrested, tried, and executed was Guy Fawkes; and the deed he and his accomplices had attempted left significant traces in the collective memory of the English: An interior, religiously motivated threat to both the monarchy and the parliamentarian system was destroyed. A well-known nursery rhyme refers to the event, and King James I subsequently proclaimed a commemoration of the foiling of the plan with the celebration of Bonfire Night on the night of November 5. Bonfire Night was celebrated by fires into which children would toss effigies of Guy Fawkes and other figures deemed undesirable by the authorities. This effigy was often fantastically decorated, as kids went around in the days prior to the bonfire asking for "a penny for the guy" to design the puppet. The OED argues that from this tradition the word "guy" emerged as a general term for "a person of grotesque appearance" and then later for "buddy," meaning that Guy Fawkes is linguistically our proverbial everybody. Putting 
on the Occupy-mask does not situate one in the rank and file of a pre-defined rebellious entity but rather reinforces individuality in the collective resistance. The mask connects its wearers with a prototypical everybody and at the same time with a changeling, as every Guy-figure was produced differently by varying groups of children. Recognizable only in a specific context (Bonfire Night), the effigies represent individual imaginations of an historical character and his intended act of rebellion (or terror) and thus are open for constant reinterpretations. This includes, as the following section shows, Fawkes' antagonist(s). The position of the mask and of its wearer is therefore one of individual defiance; yet, against whom or what is not rightly apparent.

\section{Graphic Justice and Its ambiguities in the Comic $V$ for Vendetta}

What the historiography of the gunpowder plot did not yield, though, was a clear visual memory of the conspirators. Of Guy Fawkes' face, for instance, no authentic contemporary representation survived. Several images circulated, which the historian Philip Sidney assembled in his 300-year anniversary book A History of the Gunpowder Plot in 1905. As recent as 1841 the publication of Guy Fawkes: Or the Gunpowder Treason; an Historical Romance by British writer William Harrison Ainsworth successfully popularized an image of Guy Fawkes that served as the template of the OWS-mask. Ainsworth's novel was one of many that re-imagined the gunpowder plotters as upright patriots acting against a religiously oppressive government and that had a lasting impact on both the contextualization and visualization of the gunpowder plot. Ainsworth romanticized Fawkes and employed illustrator George Cruikshank-famous for his illustrations of novels by Charles Dickens-to accompany his text with sketches. The novel became a success in Great Britain and constructed the visual memory of Guy Fawkes through an image of a prototypical 19th-century Gothic adventurer with long black hair, moustache and goatee, spiky hat, and a long black cloak. Especially salient for Occupy, though, was the franchise $V$ for Vendetta, consisting of a comic series published from 1982-1985 and a subsequent motion picture released in 2006. While it is undoubtedly the film that is best known, the questions of (social) justice as well as individual and collective resistance are very much at the forefront of the comic as well.

The comic-story by Alan Moore, graphics by David Lloyd-discusses these topics on various levels. At its very basis, though, it is a superhero comic which engages questions of personal and social justice as moral (not legal or political) issues that are embodied and enacted by one singular individual in whose own history the manifold questions surrounding justice coalesce (How can it be achieved? Who is affected by it in which way? Who is responsible for meting it out?). ${ }^{13}$

Set in Great Britain in the then-futuresque late 1990s, $V$ depicts a society that has just barely survived a major nuclear war, is governed by the fascist Norsefire-party, collectively suffers from a history of crackdowns on people described as dissidents (e.g., left-wingers, ethnic minorities, or homosexuals), and an intrusive surveillance apparatus. One of the victims of Norsefire's regime adopts the moniker $\mathrm{V}$ and, under a stylized mask of Guy Fawkes, sets out to bring down his torturers. ${ }^{14}$ Since Norsefire has already ascended to top government ranks, V's personal quest for vengeance consequently aims at the overthrow of the dictatorship. Combining his personal vendetta with a revolutionary agenda, $\mathrm{V}$ encourages the general population to revolt 
by disrupting the state surveillance system and by highjacking mass media broadcasts to send his incendiary message to the public.

Justice in $V$ for Vendetta is thus not negotiated primarily in terms of legality but regarding its moral aspects. $\mathrm{V}$ is the prototypical avenger with an agenda of revenging ethical wrongdoing, the nemesis that brings to the fore the moral corruption of the party elders as well as the unjust conditions under which the majority of British society has to suffer. These injustices include a police apparatus designed to hide morally repulsive acts committed by the party elite like pedophilia, the subjugation of the working class under production norms set by the party, and the lethal repression of any act of free speech. Although these conditions are the results of legislative actions by the dictatorial government, the comic portrays them almost without connections to any legal framework. Past legislation is only hinted at (e.g., the declaration of martial law or the passing of laws against homosexuals), thus translating living conditions from the sphere of political and social power struggles to the sphere of a moral choice between binary forces: the dictatorship or the resistance. $\mathrm{V}$ emerges as the individual (masked) actor that fights injustices on behalf of his own grievances and of the population at large.

16 The comic thus clearly follows the conventions of the superhero genre. I would like to call the notion of justice employed by classic superhero narratives "graphic justice," using a term introduced by Thomas Giddens to investigate the interstices of comics and law. In his programmatic introduction of the concept, Giddens argues that superhero comics "navigate issues of right and wrong, of morality, of retribution and vengeance, of methodologies of control" (2); yet the visual nature of comics often boils down complex social problems into personalized dualisms between good and evil. In the volume edited by Giddens, James Petty's contribution details that many graphic narratives dealing with social rights, justice and moral decisions

locate the source of criminality (and therefore justice) within the individual, often as a result of psychopathy or childhood trauma. Thus, they tend to ignore other arguably more pernicious forms of injustice such as social marginalization, systemic poverty and the exploitative and often violent activities of corporations and nation states. (Petty 149-150)

$17 V$ for Vendetta presents such an individualized narrative of good versus evil: The injustices depicted are based on socio-political conditions; yet, the necessary steps to overcome them are exclusively vested in the main character. $\mathrm{V}$ is an omnipotent prosecutor, judge, and executioner - a typical superhero following his personal code of morality and sense of justice without considering democratic legitimization. This type of "graphic justice" does not include an opportunity for redress or reconsideration, its only goal being the physical extermination of morally corrupted individuals or the overthrow of the unjust system. While $V$ for Vendetta employs this concept of justice, it repeatedly calls into question our identification with $\mathrm{V}$ and his actions. The story is replete with narrative and visual claims that $\mathrm{V}$ does not create the conditions for a just society or for the redress of former wrongdoing. The shocking ("graphic") images of minor henchmen murdered by $\mathrm{V}$ in order to close in on his major targets draw our attention to the objectifications inherent in V's dichotomous worldview, which only acknowledges friends or foes. No quarters are given by either side. $V$ thus simply reproduces the totalitarian logic of the regime, a fact underlined not only by the nagging questions of the investigating Inspector Finch-the moral guide for the reader/ viewer-but also in a subplot revolving around Rosemary Almond, the secret police 
chief's wife, who is traumatized when $\mathrm{V}$ murders her husband and who is forced to become a prostitute in the male-dominated fascist system, and who finally turns into an assassin herself. ${ }^{15}$ The readers are forced to acknowledge that $\mathrm{V}$ objectifies people as representatives of an odious system and consequently reproduces the totalitarian logic of his adversaries.

As is typical for superheroes, their actions and motivations combine individual goals with a wider social impact. In this vein, $\mathrm{V}$ in his vendetta does not only kill individual members of the dictatorship but intervenes in its symbolic order. His bombing raids target sites of democratic representation no longer in sync with the dystopian political reality and mark an attempt to establish a new society via the symbolic destruction of the old-a public performance that is very different from OWS's insistence on nonviolence. Moore's comic regards societies as simplistic social systems than can be "reset" by the actions of one (outstanding) individual, an inherently hierarchical, antidemocratic thinking.

Such a notion of social change does not involve participation by the wider population. Consequently, $V$ for Vendetta ends with a pessimistic outlook on the peoples' aptitude to wield power: Once the surveillance system is brought down, the party's leader is assassinated and the organs of oppression are in disarray, the population's revolt results in violent chaos, leading to a total social breakdown. The graphic justice meted out by superheroes is thus trapped in its own logic; a logic that negates collective power to ordinary citizens as it locates all power for change in masked avengers. As social change is negotiated in moral terms, not political ones, the narrative shifts from one of social justice to one of moral conflict. In such a narrative, only a few outstanding individuals can perform the necessary actions, which are always directed against a few other outstandingly evil individuals, as the reasons for social conditions and social struggles are transformed into and embodied by individual psychopaths. While superheroes can engage in cooperative forms of struggle (joining hands, for example, in superhero groups like the "Justice League"), their struggles remain aloof from the general populace. Although it is the transformation into a better, more just world that motivates their actions, their modus operandi does not incorporate elements of participation. In $V$ for Vendetta, the main character realizes this shortcoming and his inability to form part of a new, participatory social order. Consequently, his master plan for the destruction of the Norsefire regime includes his own destruction.

\section{Vendetta at Zuccotti Park? The Problematic Usage of the Occupy Mask}

20 The aforementioned non-participatory logic stands in stark contrast to the Occupy Wall Street logic of creating situations in which a citizenry regarded as apathetic is motivated to participate in the concrete creation of alternative futures, thus empowering them to strive for fundamental changes ${ }^{16}$ This concept of concrete utopias materialized in the semi-permanent encampments at Zuccotti Park and elsewhere harks back to what Guy Debord and his Situationist International had attempted, namely the composition of an event in which the general population could partake and thereby realize some of the possibilities of a different future-a "situation" that converted spectators into participants or even activists. ${ }^{17}$ While the Situationists attempted to create such situations via happenings and art exhibitions, the occupation 
of Zuccotti Park in New York was conceptualized in itself as a test site of artistic, social, and political situatedness: a multitude of people trying to build a horizontal decision making process, a different form of democracy, and a more just system.

The protesters in Zuccotti Park did not seek "graphic justice," i.e., the physical destruction of an ultimate evil other, but rather social justice akin to the alterglobalization movement. To this end, they regarded a broad political participation via horizontal decision-making not only as a conditio sine qua non but already in itself as a major achievement. To temporarily unite atomized individuals and to facilitate a conversation between them was already regarded as an act of politicization. OWS activists conceptualized democracy as a particular kind of doing politics, namely by establishing "a community of sharing," which mirrored internet-based discourses of sociality. For many OWS protesters the sharing of physical and conversational space at Zuccotti Park already constituted an embodiment of social justice. Many did not petition political institutions for redress for their grievances but imagined building the "socio-political and economic alternative" the "Principles of Solidarity" envisioned along the same lines as the alter-globalization movement: in the form of a confined local gathering, in which progressive people shared both physical objects (like tents or books) and a democratic voice. In their focus on equal participation in decision-making processes and the self-reliance of their encampments, though, members of ows ultimately postponed decisions on confronting the (re-)distribution of wealth and social inclusion, the fundamental principles of social justice. In the same vein as the Zapatistas, their goal was not a revolution that would overthrow political power but the establishment of alternative ways of doing politics. Yet, contrary to the Zapatistas, who acted as members of small, tightly interconnected indigenous communities, the diversity of ows became an insurmountable obstacle, which meant that the central question formulated on the call-for-action poster-"What is our one demand?"-could never be answered. Only in the physical proximity of the debating community (either at the encampments or on virtual discussion boards) could contingent answers be found. Social justice was therefore changed from a concept highlighting the economic basis for participation to a practice focusing on bodily presence, horizontal and leaderless inclusion, and a "fair" share of speaking, voting, and blocking powers in decision-making-the same conceptual change proposed by the Zapatistas for indigeneity in the 1990s.

This dialogue and consensus-based model stands in stark contrast to the revolution evoked in $V$ for Vendetta. The comic presents corrupted political institutions, which a superhero destroys violently by naming, blaming, and annihilating his antagonists. In this context of surveillance and suppression, individual freedom is the ultimate goal, and the Guy Fawkes-mask symbolizes the power of individual heroic agency and-in the film only-its temporary adoption by a mass of unified civic individuals.

In this scene, a multitude of people, all wearing V's mask, gathers in front of the Houses of Parliament to witness V's final bombing. Coming together from different directions but merging into one uniform(ed) stream in a unidirectional current, the masked crowd confronts and pacifically overruns a police cordon deployed to defend the Parliament building. Forming orderly lines of spectators, the masked populace then watches a performance revolution in the same way as we, the crowd in front of the screen, consumes the movie. The film here follows the superhero comic's logic by displaying the revolution as the work of a heroic protagonist who depends on other 
citizens only as his audience. While the film briefly established the population's potential for uprising, it still negates its agency in organization. Therefore, the organized action of revolution (in contrast to mere rioting or uprising) can occur only in the image created by V: a crowd masked in his mask, an extended body of the superhero that tacitly approves of his justice-as-vendetta.

The film then makes yet another volte-face. At the height of the bombing spectacle, the assembled spectators take off their masks and reveal their faces. Here, a tension becomes visible between the confines of V's role as a superhero protagonist and a configuration of the political that bestows revolutionary agency on a plural citizenry. The scene of "unveiling" counterposes the populace's former fear of the regime's surveillance and underlines the agency of a diverse citizenship: Different ages, sexes, and ethnicities are shown to have participated in the act of uprising, with their identities only temporarily hidden (not erased) behind V's unifying attire. Sensing the productive dialectics or simply the irony inherent in this exchange between individuality and uniformity, the Occupiers appropriated the mask with an insouciant verve that stemmed from its proximity to pseudo-anarchist imagery, and a narrow focus on a climactic scene of civic uprising that the movie adaptation of the comic inserted.

In the motion picture, the V-mask plays a double role as the accessory of the superhero and the tool of the revolutionary multitude. Yet, despite fleeting references to the power and agency of a diverse population, the film ultimately follows the narrative of the unidirectional, top-down leader that instills a revolution, which is at odds with the leaderless, horizontal decision-making process envisioned by OWS. It is therefore no surprise that it was this uncritical reading of the final scene of the movie, centering on temporary collective agency, which popularized the film and the mask with many OWS activists. The mask as the superhero accessory gestures towards a symbolic simplicity (good vs. evil) that was absent from both the theoretical discussions of the protesters as well as many of their other performances. Most of these underlined the diversity of the participants, the heterogeneity of their goals and intentions, and-most fundamentally -the abhorrence of hierarchical models of leadership. Yet, the Occupy-mask is not simply an aberration within an otherwise cogent protest movement: The founding activists' socialization in the alter-globalization movement resulted in their concentration on performative practices in lieu of theoretical clarifications. The encouragement of diversity included a discouragement to become too specific. As Todd Gitlin, among others, analyzed "what Occupy intuitively understood was that steering away from specific demands meant steering away from potentially fierce conflicts over what they ought to be. If the essentials were clear, then demandlessness was tantamount to inclusiveness" (Gitlin 110). Such a "demandlessness" facilitated the creation of a narrative that centered on the "here and now" as a viable alternative.

The presence of the mask in the midst of OWS shows the limitations of the absence of programmatic conceptions-and thus, an inherent need of performative narratives to "connect" to archetypal, yet simplistic structures. A discussion of the complex advancement of social justice in US society, which would have to focus especially on the social rights of people of color, was sidelined by this narrative but has come to the fore in subsequent activism against police brutality perpetrated against black people-the Black Lives Matter campaign. One of the icons of this campaign is the empty hoodie, which is symbolically filled with the faces of black people killed, starting with Trayvon 
Martin in 2013. This symbol's linkages with social exclusions and absences are more complex than the narrative of $V$ for Vendetta invoked by OWS. This may serve as a reminder that struggles for social justice in the United States (and beyond) remain as complex as ever.

\section{BIBLIOGRAPHY}

Ainsworth, William Harrison. Guy Fawkes: Or the Gunpowder Treason; an Historical Romance. London: G. Routledge and Sons, 1841.

Berger, Mark T. "Romancing the Zapatistas: International Intellectuals and the Chiapas Rebellion.” Latin American Perspectives 28.2 (Jan. 2001): 149-70.

Candeias, Mario, and Eva Völpel. Plätze sichern! ReOrganisierung der Linken in der Krise; zur Lernfähigkeit des Mosaiks in den USA, Spanien und Griechenland. Hamburg: VSA, 2014.

Cleaver, Jr., Harry M. “The Zapatista Effect: The Internet and the Rise of an Alternative Political Fabric.” Journal of International Affairs 51.2 (1998): 621-40.

Clifford, James. Returns: Becoming Indigenous in the Twenty-First Century. Cambridge: Harvard UP, 2013.

Conant, Jeff. A Poetics of Resistance. The Revolutionary Public Relations of the Zapatista Insurgency. Oakland: AK P, 2010.

Crouch, Colin. Post-Democracy. Malden: Polity, 2004.

Flesher Fominaya, Cristina. Social Movements and Globalization: How Protests, Occupations and Uprisings are Changing the World. Basingstoke: Palgrave Macmillan, 2014.

Giddens, Thomas. "Introduction.” Graphic Justice: Intersections of Comics and Law. Ed. Thomas Giddens. London: Routledge, 2015, 1-7.

Gitlin, Todd. Occupy Nation: The Roots, the Spirit, and the Promise of Occupy Wall Street. New York: HarperCollins, 2012.

Graeber, David. The Democracy Project: A History, a Crisis, a Movement. New York: Spiegel \& Grau, 2013.

Huffschmid, Anne. Diskursguerilla, Wortergreifung und Widersinn: die Zapatistas im Spiegel der mexikanischen und internationalen Öffentlichkeit. Heidelberg: Synchron, 2004.

Khasnabish, Alex. Zapatistas: Rebellion from the Grassroots to the Global. Halifax, New York, London: Fernwood Pub.; Zed Books; Palgrave Macmillan, 2010.

Lasn, Kalle. Culture Jam: The Uncooling of America. New York: William Morrow \& Company, 1999.

McTeigue, James. V for Vendetta. Warner Home Video, 2006.

Moore, Alan, and David Lloyd. V for Vendetta. New York: DC Comics, 1989.

Nail, Thomas. "Zapatismo and the Global Origins of Occupy." Journal for Cultural and Religious Theory 12.3 (2013): 20-35. 
Notes from Nowhere. We Are Everywhere: The Irresistible Rise of Global Anticapitalism. London: Verso, 2003.

Petty, James. "Violent Lives, Ending Violently? Justice, Ideology and Spectatorship in Watchmen." Graphic Justice: Intersections of Comics and Law. Ed. Thomas Giddens. London: Routledge, 2015, 147-63.

Raunig, Gerald. Kunst und Revolution: Künstlerischer Aktivismus im langen 20. Jahrhundert. Wien: Turia + Kant, 2005.

Rawls, John. A Theory of Justice. Cambridge: Belknap P, 1994.

Schneider, Nathan. Thank You, Anarchy: Notes from the Occupy Apocalypse. Berkeley: U of California P, 2013.

Sidney, Philip. A History of the Gunpowder Plot: The Conspiracy and Its Agents ... with Facsim. Illus. from Old Prints. London: The Religious Tract Society, 1905.

Sitrin, Marina, and Dario Azzellini. They Can't Represent Us!: Reinventing Democracy from Greece to Occupy. London: Verso, 2014.

Sobral, Ana. “Towards a ‘World Revolution'? Forging a Transnational Emancipation Narrative from Tahrir Square to Wall Street." From Popular Goethe to Global Pop. Ed. Ines Detmers and Birte Heideman. Amsterdam: Rodopi, 2013, 229-53.

Taussig, Michael Thomas. "I’m So Angry, I Made a Sign.” Occupy: Three Inquiries in Disobedience. Ed. W.J.T Mitchell, Bernard Harcourt, and Michael T. Taussig. Chicago: U of Chicago P, 2013, 3-45.

Taylor, Astra, ed. Occupy!: Scenes from Occupied America. London: Verso, 2011.

Winter, Jens. "Polit-Konjunkturen und effektive Konzeptlosigkeit: Wieso fasziniert die 'indigene Tradition' südmexikanischer Bauern?” Chiapas und die Internationale der Hoffnung. Ed. REDaktion. Köln: Neuer ISP Verlag, 1997, 166-77.

\section{NOTES}

1. Good introductions to the OWS-protests by critical participant observers are the books by Schneider and Taylor. For an international contextualization by activists, see Sitrin and Azzellini. 2. This declaration was passed by the General Assembly in Zuccotti Park but-as all documents by the protesters-was not intended to reflect the movement in general. All positions expressed in it reflect only those of the Assembly's participants on that particular day. See: http:// www.nycga.net/resources/documents/principles-of-solidarity/.

3. Occupy Wall Street started with a campaign ignited by the Canadian culture-jamming magazine Adbusters, which between February and June 2011 floated the slogan "Occupy Wall Street" around the internet, without specifying any details. The initial call-for-action poster showed a ballerina superimposed on the famous charging bull-statue of Wall Street in front of a backdrop of tear gas-throwing riot police, accompanied by the question: "What is our one demand?" Apart from that question, the poster only included the Twitter hashtag \#occupywallstreet, the date September $17^{\text {th }}$, and the request "Bring tent." See Lasn for a description of the Adbusters concept and Graeber (esp. 3-54) for a first-hand narrative of the organizational efforts prior to the occupation.

4. OWS's focus on the mortgage crisis is visible in the wording of the "Principles of Solidarity," which urges the protesters to "reclaim our mortgaged future." The protests were organized by the same college-educated demographic that had supported Barack Obama's 2008 presidential 
campaign and thus felt disappointed by the president's lackluster approach towards the systemic crisis (see Gitlin 3).

5. The widespread moniker "anti-globalization" movement is a misnomer as the goal of the movement was not to stop globalization but to alter it.

6. From the immense body of literature on the alter-globalization movement, a good introduction is the reader by the eponymous Notes from Nowhere-collective. A more critical approach, written with hindsight, is the one by Flesher Fominaya.

7. See Nail and Gitlin for this continuity and Graeber (150-207) as well as Sitrin (9) for first-hand descriptions of their inspiration by the Zapatistas, the 1999 anti-WTO protests in Seattle, and the alter-globalization movement. An early, clairvoyant analysis of the Zapatistas' longevity is by Cleaver, Jr.

8. From the bulk of Zapatista-related material, Huffschmid is still a major contribution on its international medial reverberations. See also Conant, Khasnabish and, for a critical perspective on racial stereotyping in the Zapatista solidarity movement, Berger.

9. Very few initiatives were started by OWS activists to connect their protests with similar struggles in other countries or to link their national demands with the economic policies of transnational bodies like the World Bank. This stands in stark contrast to the occupations in Spain and Greece, where such a transnational paradigm was pivotal as Candeias and Völpel argue.

10. It should be reiterated that the usage of masks varied considerably between the different national or local configurations of the protests. As one of the functions of masks is the disguise of an individual's face to escape prosecution, different legal codes encouraged or discouraged the veiling of one's face.

11. On new, open forms of indigeneity see Clifford as a cautiously positive and Winter as a critical voice.

12. The phrase in the Spanish original says "Detrás de nosotros, estamos ustedes."

13. Moore would go on to write Watchmen from 1986 to 1987 (graphics by Dave Gibbons), in which he explicitly challenges and subverts the conventions and logics of the superhero genre (e.g., with its tagline "Who watches the watchmen?"), but in $V$ he still uses a more-than-human vigilante to confront an unjust system.

14. The text clearly references the historical Guy Fawkes as a model for V's vengeance: To instil revolt, $\mathrm{V}$ plants and explodes bombs under the Houses of Parliament as well as 10 Downing Street and old Bailey as symbols of the institutional branches of representative democracy nullified by the fascist dictatorship.

15. This sub-plot draws attention to the gendered nature of Moore's dystopian Britain (intended to mirror Thatcherite Britain), where women depend on male custodians to advance socially.

16. Discussions about political apathy and "post-democracy" became virulent in the aftermath of Colin Crouch's 2004 eponymous study. Crouch argues that democracy (as an institutional form of representative political participation) is endangered; yet not, as in the past, by open advocacy of anti-democratic forms of government (e.g., fascism) but rather via more hidden and thus more menacing shenanigans. Decision-making has been taken away from democratic institutions by economic elites, who uphold the facade of egalitarian participation but control processes of deliberation and decision-making through their economic power in a transnational ("globalized") network and act in cahoots with the executive powers of various nation states. According to Crouch, the citizenry is aware of this development but partakes in the prolonged masquerade of democracy because viable alternatives are rendered unrealistic.

17. On the impact of the Situationists on protest movements in the long $20^{\text {th }}$ century see Raunig

(7-22, 154-240). 


\section{ABSTRACTS}

The essay analyzes concepts of social justice, which were influential during the US-American Occupy protests of 2011. It discusses the recent genealogy of notions of social justice in the alterglobalization movements of the 1990s and argues that constitutive elements of Occupy's tactics, like carnivalesque frivolity, recurred to protest forms of that decade. The essay investigates how the usage of the Guy Fawkes-mask, later associated with the comic superhero V, complicates binary logics of good and evil, arguing that such binary narratives helped in the organizational phase of the protests, but turned out to be inimical to further discussions of what constitutes social justice in the 21st century.

\section{INDEX}

Keywords: Alan Moore, alter-globalization, comics, graphic justice, Guy Fawkes, mask, masking, Occupy Wall Street, protest movements, social justice, superhero comic, V for Vendetta, Zapatistas

\section{AUTHOR}

\section{ANDREAS BEER}

Andreas Beer is an American Studies scholar, holding a PhD from Rostock University and now working at the Martin-Luther University Halle-Wittenberg. After investigating transnational filibustering activities in the 19th century, his current research focuses on movements of dissent and non-representation in the Americas. More on his research, academic activities and extracurricular meanderings can be found at: andreasbeer.info. 